
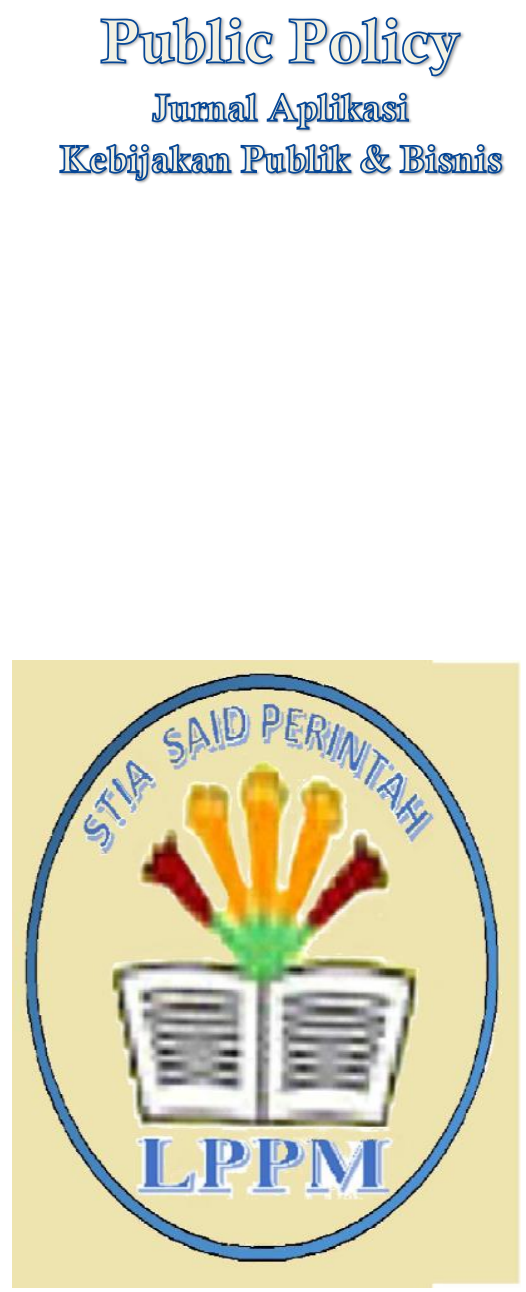

Volume 1, No. 1, Maret 2020

LPPM STIA Said Perintah

stia-saidperintah.e-journal.id

\section{Dampak Lingkungan Kerja Fisik dan Lingkungan Kerja Non Fisik Terhadap Kepuasan Kerja Karyawan}

\author{
Herman Surijadi \\ Administrasi Bisnis Politeknik Negeri Ambon \\ hermansurijadi@yahoo.co.id \\ Yuslan Idris \\ Program Studi Niaga STIA Said Perintah \\ tabloid.teropong@yohoo.com
}

\begin{abstract}
The aim of this study is to examine and analyze the effect of physical and non-physical working environment on the employee working satisfaction. The population in this study are all employees of Matahari Department store in Ambon City Center (ACC) in Ambon. The sampling technique used in this study is census technique with 79 respondents as final amount of sample. Data collection in this study is taken using questionnaire, while the analysis of the data to answer the research question used multiple linier Regression analysis.

The result shows that the physical and non-physical working environment proven to have positive and significant impact on the employees working satisfaction in Matahari Department store in Ambon City Center (ACC) in Ambon City. This is shown by regression coefision of physical and non-physical working environment in which if they increase, it is followed by the increase of employees working satisfaction. Thus, it can be said that the increase of physical and non-physical working environment value will increase the employees working satisfaction in Matahari Department store in Ambon City Center in Ambon.
\end{abstract}

Keywords : Physical Work Environment, Non-Physical Work Environment, Job Satisfaction 


\section{Pendahuluan}

Kepuasan kerja ini selalu menjadi salah satu topik yang selalu ramai didiskusikan karena menjadi salah datu deteminan mutlak terhadap kepuasan kerja atau karyawan. Pernyataan ini didasarkan pada maraknya pemberitaan menyangkut kepuasan kerja seperti yang dilansir dari Accenture, sebuah lembaga konsultasi bisnis dan manajemen asal Amerika Serikat mengeluarkan hasil studi terbaru mereka pada Maret 2013 (http://www.medanbisnisdaily.com, 2014). Studi yang mempelajari tingkat kepuasan kerja pada karyawan itu menunjukkan pekerja/karyawan yang bekerja di Indonesia termasuk yang paling tidak bahagia di dunia.

Menurut Accenture, Indonesia berada diurutan pertama negara tempat orang-orang memiliki tingkat kepuasan dan kebahagiaan terendah di dunia. Masalah insentif dan keseimbangan karier serta kehidupan personal (keseimbangan waktu antara bekerja dan menikmati waktu bersama keluarga) dianggap menjadi penyebab utama indeks ini. Mereka juga menambahkan bahwa hanya $18 \%$ dari kelompok responden karyawan di Indonesia yang mengatakan puas dengan kualitas kehidupan serta kebahagiaannya ditempat kerja. Ini menempatkan Indonesia diposisi paling bawah tingkat kepuasan para pekerja (http://www.medanbisnisdaily.com, 2014).

Sumber lain yakni, Dale Carnegie melalui studinya yang bertajuk Global Leadership Study, memperlihatkan bahwa lebih dari 30 persen tenaga kerja di Indonesia akan mencari pekerjaan baru dalam waktu dekat, bahkan $13 \%$ bahkan mengaku saat ini sedang dalam pencarian pekerjaan baru yang penyebabnya adalah ketidakpuasan dalam pekerjaan (lifestyle.kompas.com, 2018) Penelitian tersebut juga menyebutkan bahwa 85\% karyawan menganggap apresiasi dan pujian dari atasan terhadap pekerjaan yang mereka lakukan sangatlah penting. Namun, pada praktiknya hanya 36 persen atasan yang melakukannya," tutur Joshua Siregar selaku Director, National Marketing Dale Carnegie Indonesia. Salah satu penyebab ketidakpuasan ini adalah lingkungan kerja seperti yang disampaikan oleh Ketua Pengurus Pusat Perhimpunan Dokter Spesialis Jiwa Dr Eka Viora SpKJ (gaya.tempo.co, n.d.) bahwa lingkungan kerja yang tidak 
sehat ini pada akhirnya akan berdampak pada ketidakhadiran, rendahnya motivasi dan kinerja serta hilangnya produktivitas.

Fakta tersebut diatas ternyata berjalan lurus dengan hasil kajian ilmiah kepuasan kerja di Indonesia seperti yang pernah disampaikan oleh (Pangarso, 2015) melalui hasil penelitiannya menyatakan bahwa lingkungan kerja (non fisik) berpengaruh signifikan terhadap kepuasan kerja dosen tetap fakultas komunikasi dan bisnis universitas Telkom bandung. Hasil ini didukung oleh hasil kajian (Marezza Putri Anggreani, 2016) yang juga mengakui bahwa lingkungan kerja non fisik berpengaruh signifikan terhadap kepuasan kerja karyawan pada PT. Andhika Lintas Samudra Banjarmasin.

Peneliti lain yakni (Dwi Silvia Eka S., 2016) menunjukan bahwa lingkungan kerja fisik dan non fisik terbukti berpengaruh positif dan signifikan terhadap kepuasan kerja. Hasil yang sejalan juga disampaikan oleh (Untung Dasio dan Nugraheni Rini, 2017) yang berhasil membuktikan bahwa lingkungan kerja fisik dan lingkungan kerja non fisik berpengaruh positif dan signifikan terhadap kepuasan kerja. Hasil yang sama juga disampaikan oleh (Zulfahmi Septian
Dwi Pangestu, 2017) bahwa lingkungan kerja fisik dan lingkungan kerja non fisik berpengaruh signifikan terhadap kepuasan kerja karyawan pada Perum Perhutani Ngawi.

Namun, tidak semua hasil kajian menunjukan bahwa lingkungan kerja baik fisik maupun non fisik berpengaruh terhadap tingkat kepuasan kerja. Hal ini disampaikan oleh (Jasman Saripuddin, 2015) yang berhasil membuktikan bahwa tidak terdapat pengaruh antara lingkungan kerja terhadap kepuasan kerja pada PT. Sarana Agro Nusantara Medan. Hasil kajian diatas kemudian juga didukung oleh (Tukijan, 2016) yang menyatakan bahwa walaupun lingkungan kerja non fisik berpengaruh secara parsial terhadap kepuasan kerja pegawai pada STISIP Amal IImiah Yapis Wamena namun tidak demikian dengan lingkungan kerja non fisik. Kedua hasil kajian diatas juga didukung oleh hasil kajian (M. Sandi Marta dan Budi, 2019) yang juga berhasil membuktikan bahwa lingkungan kerja fisik tidak berpengaruh terhadap kepuasan kerja.

Pemaparan hasil-hasil kajian empiris diatas menunjukan bahwa ada kontradiksi atau ambivalensi hasil penelitian menyangkut dampak atau pengaruh lingkungan kerja fisik dan lingkungan kerja terhadap kepuasan kerja/karyawan. Kontradiksi atau 
ambivalensi hasil penelitian ini yang oleh (Agusty Ferdinand, 2006) disebut sebagai celah penelitian (research gap) yang dapat diteliti kembali oleh peneliti lain. Hal inilah yang memotivasi peneliti untuk meneliti tentang dampak lingkungan kerja fisik dan lingkungan kerja non fisik terhadap kepuasan kerja dengan lokasi/objek penelitian yang berbeda yakni pada Matahari Depaterment Strore di Kota Ambon. Berdasarkan pemaparan fakta dan hasil kajian empiris diatas maka peneliti memutuskan untuk mengkaji dan menanalisis lebih dalam lagi tentang dampak lingkungan kerja fisik dan lingkungan kerja non fisik terhadap kepuasan kerja karyawan Matahari Depaterment Strore pada Ambon City Centre (ACC) di Kota Ambon. Diharapkan hasil temuan penelitian ini dapat mengurangi kontradiksi atau ambivalensi hasil penelitian yang telah dijabarkan diatas.

\section{Tinjauan Pustaka}

\section{Lingkungan Kerja}

(Sedarmayanti, 2001) mendefinisikan lingkungan fisik dalam arti semua keadaan yang terdapat disekitar tempat kerja, akan mempengaruhi pegawai baik secara langsung maupun tidak langsung.
Lingkungan fisik dapat dibagi dalam dua kategori, yaitu;

1. Lingkungan yang langsung berhubungan dengan pegawai (seperti; pusat kerja, kursi, meja dan sebagainya)

2. Lingkungan perantara atau lingkungan umum (seperti; rumah, kantor, pabrik, sekolah, kota, sistem jalan raya, dan lain-lain)

Sementara lingkungan perantara, dapat juga disebut lingkungan kerja yang mempengaruhi kondisi manusia, misalnya: temperatur, kelembaban, sirkulasi udara, pencahayaan, kebisingan, getaran mekanis, bau tidak sedap, warna, dan lain-lain.

Selain lingkungan kerja secara fisik, lingkungan kerja yang tidak menyenangkan juga bisa disebabkan karena suasana kerja yang tidak kondusif, seperti adanya persaingan, teman sekerja saling menjatuhkan, dan adanya kerja sama yang jelek. Suasana kerja yang tidak mendukung seperti itulah yang membuat karyawan tidak kerasan kerja.

\section{Lingkungan Kerja Fisik}

(Moekijat, 1995) mengatakan, lingkungan fisik adalah sesuatu yang berada disekitar para pekerja yang meliputi cahaya, warna, udara serta musik yang mempengaruhi dirinya dalam menjalankan tugas-tugas yang 
dibebankan. Lingkungan fisik yang tidak membahayakan serta menyenangkan akan menimbulkan kepuasan kerja karyawan, yang pada akhirnya akan mendorong karyawan untuk tetap tinggal diorganisasi. Unsur didalam lingkungan fisik meliputi sebagai berikut; fasilitas, penerangan, warna, udara, suara dan music.

\section{Lingkungan Kerja Non Fisik}

Lingkungan kerja non fisik merupakan kelompok lingkungan kerja yang tidak bisa diabaikan. Pengertian lingkungan non fisik telah dikemukakan oleh beberapa ahli, diantaranya yakni (Sedarmayanti, 2001) yang menyatakan bahwa, lingkungan kerja non fisik adalah semua keadaan yang terjadi yang berkaitan dengan hubungan sesama rekan kerja, ataupun hubungan dengan bawahan. Hubungan kerja dibagi menjadi dua;

a. Hubungan kerja antar pegawai

Hubungan kerja antar pegawai sangat diperlukan dalam melakukan pekerjaan, terutama bagi pegawai yang bekerja secara berkelompok, apabila terjadi konflik yang timbul dapat memperkeruh suasana kerja dan akan menurunkan semangat kerja pegawai.

b. Hubungan kerja antar pegawai dengan pimpinan
Sikap atasan terhadap bawahan memberikan pengaruh bagi pegawai dalam melaksanakan aktivitas. Sikap yang bersahabat, saling menghormati perlu dalam hubungan antar atasan dengan bawahan untuk kerjasama dalam mencapai tujuan perusahaan.

Duane et al., dalam (Mangkunegara, A.A., dan Prabu, 2011) mengatakan bahwa lingkungan kerja non fisik adalah semua aspek fisik psikologis kerja, dan peraturan kerja yang dapat mempengaruhi kepuasan kerja dan pencapaian produktivitas. Lingkungan kerja non fisik terdiri dari lingkungan kerja temporal dan lingkungan kerja psikologis. Menurut (Sunyoto, 2012) hubungan rekan kerja dalam lingkungan kerja non fisik dibagi menjadi dua, yaitu hubungan individu dan hubungan kelompok. Pendapat lain oleh (Wursanto, 2009) yang mengatakan bahwa lingkungan kerja non fisik sebagai sesuatu yang menyangkut segi psikis dari lingkungan kerja.

Berdasarkan

pengertianpengertian tersebut dapat dikatakan bahwa lingkungan kerja non fisik disebut sebagai lingkungan kerja psikis, yaitu keadaan disekitar tempat kerja yang bersifat non fisik. Lingkungan kerja yang seperti ini tidak dapat 
ditangkap langsung dengan panca indra manusia, namun dapat dirasakan keadaannya. Lingkungan kerja non fisik ini dapat dirasakan melalui hubunganhubungan sesama karyawan, bawahan dengan atasan, maupun atasan dengan bawahan.

\section{Kepuasan Kerja}

Kepuasan kerja merupakan suatu perasaan yang diinginkan oleh setiap pekerja. Kepuasan kerja dapat diartikan sebagai selisih antara harapan dan kenyataan yang diterima seorang pekerja atau keadaan emosional pekerja yang menyenangkan atau tidak menyenangkan terhadap pekerjaannya. Menurut (Robbins, S. P., 2002) kepuasan kerja merujuk pada sikap umum seorang individu terhadap pekerjaannya, sehingga seseorang dengan tingkat kepuasan kerja tinggi akan menunjukkan sikap positif terhadap pekerjaannya. Sebaliknya jika seseorang tidak puas dengan pekerjaaannya akan menunjukkan sikap negatif terhadap pekerjaannya.

Selanjutnya (Fred Luthans, 2002) menyatakan bahwa kepuasan kerja menyangkut beberapa hal pokok antara lain :

a. Kepuasan kerja tidak dapat dilihat, tetapi hanya dapat diduga keberadaannya karena kepuasan kerja menyangkut persoalan emosi atau respons pekerja dari situasi kerja yang dihadapi.

b. Kepuasan kerja menyangkut kesesuaian hasil kerja yang diperoleh dengan harapan para pekerja.

c. Kepuasan kerja sangat terkait erat dengan persoalan; pekerjaan itu sendiri, kesempatan promosi, gaji, supervisor maupun rekan kerja.

Berdasarkan beberapa pengertian diatas, dapat disimpulkan bahwa kepuasan kerja sangat tergantung pada perbedaan antara harapan dan kenyataan yang dirasakan pekerja terhadap pekerjaannya termasuk lingkungan kerjanya. Seorang pekerja akan merasa puas jika harapannya terhadap pekerjaan termasuk lingkungan kerjanya terwujud. Beberapa teori kepuasan kerja, (Mangkunegara, A.A., dan Prabu, 2011) antara lain :

a. Teori Keseimbangan (Equity Theory); Dikembangkan oleh Adam, dengan komponennya yaitu input, outcome, comparison person, dan equity-in-equity. Teori ini menjelaskan bahwa puas atau tidak puasnya pegawai merupakan hasil dari membandingkan input-outcome dirinya dengan perbandingan inputoutcome pegawai lainnya. 
b. Teori Perbedaan (Discrepancy Theory); Dipelopori oleh Proter. Ia berpendapat bahwa mengukur kepuasan dapat dilakukan dengan cara menghitung selisih antara apa yang seharusnya dengan kenyataan yang dirasakan pegawai. Apabila yang didapat pegawai ternyata lebih besar daripada apa yang diharapkan maka pegawai tersebut puas. Begitu pula sebaliknya apabila kebutuhan pegawai tidak terpenuhi, pegawai itu akan merasa tidak puas.

c. Teori Pemenuhan Kebutuhan (Need Fulfillment Theory); Teori ini menjelaskan bahwa kepuasan pegawai tergantung pada terpenuhi tidaknya kebutuhan pegawai.

d. Teori Pandangan Kelompok (Sosial Reference Group Theory); Kepuasan kerja bukanlah bergantung pada pemenuhan kebutuhan saja, tetapi sangat bergantung pada pandangan dan pendapat kelompok yang oleh para pegawai dianggap sebagai kelompok acuan. Jadi pegawai akan merasa puas apabila hasil kerjanya sesuai dengan minat dan kebutuhan yang diharapkan oleh kelompok acuan.

e. Teori dua Faktor dari Herzberg; Teori ini menjadikan teori Maslow sebagai acuannya. Dua faktor yang dapat menyebabkan timbulnya rasa puas atau tidak puas yaitu; (1) faktor pemeliharaan meliputi administrasi dan kebijakan perusahaan, kualitas pengawasan, hubungan dengan pengawas, hubungan dengan subordinate, upah, keamanan kerja, kondisi kerja dan status. (2) faktor pemotivasian, yang meliputi dorongan berprestasi, pengenalan, kemajuan, pekerjaan itu sendiri, kesempatan berkembang dan tanggung jawab.

f. Teori pengharapan (Exceptancy Theory); Teori ini dikembangkan oleh Vroom, kemudian diperluas oleh Porter, Lawler dan Davis. Motivasi merupakan suatu produk dari bagaimana seseorang menginginkan sesuatu, dan penaksiran seseorang memungkinkan aksi tertentu yang akan menentukannya. Dimana kekuatan hasrat seseoang untuk mencapai sesuatu (valensl) dikalikan harapan (kemungkinan mencapai sesuatu dengan aksi tertentu) akan menghasilkan motivasi (kekuatan dorongan yang mempunyai arah pada tujuan tertentu). Produk dari valensi dan harapan adalah motivasi yang meningkatkan dorongan dalam diri 
pegawai untuk melakukan aksi untuk mencapai tujuannya. Aksinya dapat dilakukan pegawai dengan cara berusaha lebih besar atau mengikuti kursus pelatihan. Hasil yang akan dicapai secara primer adalah promosi jabatan, dan gaji lebih tinggi. Hasil sekundernya, antara lain status menjadi lebih tinggi, pengenalan kembali, keputusan membeli produk dan pelayanan keinginan keluarga, dengan demikian lebih besar dorongan pegawai dalam mencapai kepuasan.

Dalam praktiknya sering ditemukan kepuasan kerja berhubungan dengan beberapa variabel seperti; turnover, tingkat absensi, umur, tingkat pekerjaan, ukuran organisasi dan kinerja. Kepuasan kerja yang tinggi dihubungkan dengan turnover pagawai yang rendah, sebaliknya pekerja yang tidak puas umumnya turnover yang tinggi dan atau tingkat absensinya tinggi. Ketidakhadiran mereka sering dengan alasan yang tidak logis dan subjektif (Tamaela Eduard \& Surijadi Herman, 2014). Ketidakpuasan pekerja juga sering dinyatakan dengan berbagai cara. Misalnya berhenti bekerja, mengeluh, tidak patuh, mencuri milik organisasi atau mengelak dari tanggunga-jawab kerja mereka. Lebih spesifik dikemukakan beberapa faktor yang mempengaruhi kepuasan kerja. (Robbins, S. P., 2002) menyatakan ada 4 (empat) faktor yang mendorong kepuasan kerja yaitu; pekerjaan yang secara mental menantang, ganjaran (pendapatan dan penghargaan) yang setimpal, kondisi kerja yang mendukung dan mitra kerja yang yang mendukung.

Selanjutnya (Mangkunegara, A.A., dan Prabu, 2011) menyebutkan ada dua faktor yang mempengaruhi kepuasan kerja yaitu;

a. Faktor pegawai, yaitu kecerdasan (IQ), kecakapan khusus, umur, jenis kelamin, kondisi fisik, pendidikan, pengalaman kerja, masa kerja, kepribadian, emosi, cara berpikir, persepsi, dan sikap kerja.

b. Faktor pekerjaan, yaitu jenis pekerjaan, struktur organisasi, pangkat (golongan), kedudukan, mutu pengawasan, interaksi sosial, dan hubungan kerja.

\section{Penelitian Terdahulu \\ Pengembangan Hipotesa}

dan

Kerangka konseptual kajian ini didasarkan pada tinjauan kepustakaan dan hasil penelitian terdahulu yang selanjutnya digunakan untuk kepentingan pengembangan hipotesa 
penelitian. Beberapa hasil kajian terdahulu yang mendasari pengembangan hipotesa kajian ini antara lain; (Pangarso, 2015) melalui hasil penelitiannya menyatakan bahwa lingkungan kerja (non fisik) berpengaruh signifikan terhadap kepuasan kerja dosen tetap fakultas komunikasi dan bisnis universitas Telkom bandung. Hasil ini didukung oleh hasil kajian (Marezza Putri Anggreani, 2016) yang juga mengakui bahwa lingkungan kerja non fisik berpengaruh signifikan terhadap kepuasan kerja karyawan pada PT.Andhika Lintas Samudra Banjarmasin.

Peneliti lain yakni (Dwi Silvia Eka S., 2016) menunjukan bahwa lingkungan kerja fisik dan non fisik terbukti berpengaruh positif dan signifikan terhadap kepuasan kerja. Hasil yang sejalan juga disampaikan oleh (Untung Dasio dan Nugraheni Rini, 2017) yang berhasil membuktikan bahwa lingkungan kerja fisik dan lingkungan kerja non fisik berpengaruh positif dan signifikan terhadap kepuasan kerja. Hasil yang sama juga disampaikan oleh (Zulfahmi Septian Dwi Pangestu, 2017) bahwa lingkungan kerja fisik dan lingkungan kerja non fisik berpengaruh signifikan terhadap kepuasan kerja karyawan pada Perum Perhutani Ngawi.

Namun, tidak semua hasil kajian menunjukan bahwa lingkungan kerja baik fisik maupun non fisik berpengaruh terhadap tingkat kepuasan kerja. Hal ini disampaikan oleh (Jasman Saripuddin, 2015) yang berhasil membuktikan bahwa tidak terdapat pengaruh antara lingkungan kerja terhadap kepuasan kerja pada PT. Sarana Agro Nusantara Medan. Hasil kajian diatas kemudian juga didukung oleh (Tukijan, 2016) yang menyatakan bahwa walaupun lingkungan kerja non fisik berpengaruh secara parsial terhadap kepuasan kerja pegawai pada STISIP Amal IImiah Yapis Wamena namun tidak demikian dengan lingkungan kerja non fisik. Kedua hasil kajian diatas juga didukung oleh hasil kajian (M. Sandi Marta dan Budi, 2019) yang juga berhasil membuktikan bahwa lingkungan kerja fisik tidak berpengaruh terhadap kepuasan kerja.

Berdasarkan landasan teori pada bagian tinjauan pustaka diatas dan hasil-hasil kajian terdahulu maka hipotesa yang diajukan untuk selanjutnya diuji kembali dalam kajian ini adalah;

$\mathrm{H}_{1}$; Lingkungan kerja fisik berpengaruh positif terhadap kepuasan kerja karyawan 
Matahari Depaterment Strore pada Ambon City Centre (ACC) di Kota Ambon.

$\mathrm{H}_{2}$; Lingkungan kerja non fisik berpengaruh positif terhadap kepuasan kerja karyawan Matahari Depaterment Strore pada Ambon City Centre (ACC) di Kota Ambon.

\section{Metode Penelitian}

Penelitian ini digolongkan sebagai penelitian penjelasan (eksplanatory) karena berupaya untuk menjelaskan pengaruh lingkungan kerja non fisik fisik dan lingkungan kerja non fisik terhadap kepuasan kerja. Pendekatan dalam penelitian ini termasuk dalam penelitian kuantitatif. Model penelitiannya adalah model survei dengan menggunakan instrument kuesioner. Sampel dalam kajian ini adalah karyawan Matahari Depaterment Strore pada Ambon City Centre (ACC) di Kota Ambon yang berjumlah 79 karyawan. Alat analisis yang digunakan untuk menjawab masalah penelitian adalah analisis regresi linier berganda dengan persamaan sebagai berikut;

$Y=a+\beta_{1} X_{1}+\beta_{2} X_{2}+\varepsilon$

Keterangan;

$\mathrm{Y}=$ Kepuasan kerja

$\mathrm{a}=$ Intercept

$\beta=$ Koefisien Regresi

$\mathrm{X}_{1}=$ Lingkungan Kerja Fisik
$\mathrm{X}_{2}=$ Lingkungan Kerja Non Fisik

$\varepsilon=$ Residual

Uji hipotesis dalam penelitian ini menggunakan uji $\mathrm{t}$ dengan tingkat signifikannya $5 \%$. Kriteria pengujiannya adalah; jika $\mathrm{t}$ hitung $>\mathrm{t}$ tabel maka $\mathrm{HO}$ ditolak dan Ha diterima artinya terdapat pengaruh lingkungan kerja fisik dan lingkungan kerja non fisik terhadap kepuasan kerja karyawan Matahari Depaterment Strore pada Ambon City Centre (ACC) di Kota Ambon.

\section{Hasil dan Pembahasan}

\section{Distribusi Frekuensi Jawaban}

\section{Responden}

Analisis statistik deskriptif ini dimaksudkan untuk mengetahui distribusi frekuensi jawaban responden dari hasil kuesioner yang telah disebarkan. Analisis ini bersifat memberikan makna secara deskriptif dan kecenderungan yang muncul mengenai variabel penelitian sesuai dengan hasil dari data tanpa menarik suatu kesimpulan berarti. Untuk mendapatkan kecenderungan jawaban responden terhadap jawaban masingmasing variabel akan didasarkan pada nilai rata-rata skor jawaban yang selanjutnya akan dikatagorikan pada rentang skor berikut ini;

- Skor Minimum = 1

- Skor Maksimum = 5

$$
5-1
$$


- Lebar Skala

$$
\begin{array}{ll}
5 & 0.8
\end{array}
$$

Dengan demikian maka katagori skala ditentukan sebagai berikut;

$1.00-1.80=$ Sangat Tidak Setuju

$1.81-2.60=$ Tidak Setuju

$2.61-3.40=$ Netral

$3.41-4.20=$ Setuju

$4.21-5.00=$ Sangat Setuju

Hasil pengujian statistik deskriptif

lingkungan kerja fisik, lingkungan kerja

non fisik dan kepuasan kerja dengan

menggunakan teknik pengukuran

angka indeks rata-rata terlihat lengkap

berikut ini.

\section{Distribusi Frekuensi Lingkungan}

\section{Kerja Fisik}

Berikut ini adalah deskripsi frekuensi jawaban responden mengenai lingkungan kerja fisik.

Distribusi Frekuensi

\begin{tabular}{|c|c|c|c|c|c|c|}
\hline \multirow{3}{*}{ Item } & \multicolumn{5}{|c|}{ Skor } & \multirow{3}{*}{$\begin{array}{l}\text { Rata- } \\
\text { rata }\end{array}$} \\
\hline & 1 & 2 & 3 & 4 & 5 & \\
\hline & $\mathbf{F}$ & $\mathbf{F}$ & $F$ & $F$ & $F$ & \\
\hline$X_{1.1}$ & - & 8 & 40 & 31 & - & 3.29 \\
\hline $\mathrm{X}_{1.2}$ & 8 & 5 & 40 & 26 & - & 3.06 \\
\hline$X_{1.3}$ & - & 12 & 44 & 23 & - & 3.14 \\
\hline $\mathrm{X}_{14}$ & 3 & 6 & 51 & 19 & - & 3.09 \\
\hline \multicolumn{6}{|c|}{ Total rata-rata ; } & 3.14 \\
\hline \multicolumn{7}{|c|}{$\begin{array}{l}\text { Keterangan : } 1=\text { Sangat tidak setuju; } 2= \\
\text { Tidak setuju; } 3=\text { Ragu-ragu; } 4=\text { Setuju; } 5= \\
\text { Sangat setuju }\end{array}$} \\
\hline
\end{tabular}

Lingkungan Kerja Fisik

Hasil analisis jawaban responden

menyangkut lingkungan kerja fisik yang diukur melalui 5 pernyataan dengan nilai rata-rata sebesar 3.14 yang berarti bahwa responden ternyata memilih netral dengan seluruh item pernyataan pernyataan tentang lingkungan kerja fisik. Item pernyataan yang relatif lebih baik dalam menjelaskan variabel ini adalah item pernyataan fasilitas kerja yang disediakan perusahaan $\left(X_{1 \cdot 1}\right)$ dengan nilai rata-rata tertinggi yakni 3.29 .

\section{Distribusi Frekuensi Lingkungan}

\section{Kerja Non Fisik}

Berikut ini adalah deskripsi frekuensi jawaban responden mengenai lingkungan kerja non fisik.

\section{Distribusi Frekuensi}

\begin{tabular}{|c|c|c|c|c|c|c|}
\hline \multirow{3}{*}{ Item } & \multicolumn{5}{|c|}{ Skor } & \multirow{3}{*}{$\begin{array}{l}\text { Rata- } \\
\text { rata }\end{array}$} \\
\hline & 1 & 2 & 3 & 4 & 5 & \\
\hline & $\mathbf{F}$ & $\mathbf{F}$ & $\mathbf{F}$ & $\mathbf{F}$ & $\mathbf{F}$ & \\
\hline$X_{2.1}$ & 2 & 7 & 59 & 11 & - & 3.00 \\
\hline$X_{2.2}$ & 5 & 9 & 39 & 26 & - & 3.09 \\
\hline$X_{2.3}$ & - & 9 & 48 & 22 & - & 3.16 \\
\hline$X_{2.4}$ & 2 & 6 & 61 & 10 & - & 3.00 \\
\hline \multicolumn{6}{|c|}{ Total rata-rata ; } & 3.06 \\
\hline
\end{tabular}

Lingkungan Kerja Non Fisik

Keterangan : 1 = Sangat tidak setuju; 2 = Tidak setuju; 3 = Ragu-ragu; 4 = Setuju; 5 = Sangat setuju

Hasil analisis diatas menyangkut lingkungan kerja non fisik yang diukur melalui 4 item pernyataan dengan nilai rata-rata sebesar 3.06 yang berarti bahwa responden lebih memilih netral dengan seluruh item pernyataan pernyataan tentang lingkungan kerja non fisik. Item pernyataan yang relatif lebih baik dalam menjelaskan variabel ini adalah item pernyataan hubungan atasan dan bawahan $\left(\mathrm{X}_{2 \cdot 3}\right)$ dengan nilai rata-rata tertinggi yakni 3.16.

\section{Distribusi Frekuensi Kepuasan}

\section{Karyawan}


Berikut ini adalah deskripsi frekuensi jawaban responden mengenai kepuasan karyawan.

\section{Distribusi Frekuensi}

Kepuasan Karyawan

\begin{tabular}{|c|c|c|c|c|c|c|}
\hline \multirow{3}{*}{ Item } & \multicolumn{5}{|c|}{ Skor } & \multirow{3}{*}{$\begin{array}{l}\text { Rata- } \\
\text { rata }\end{array}$} \\
\hline & 1 & 2 & 3 & 4 & 5 & \\
\hline & $F$ & $F$ & $F$ & $F$ & $F$ & \\
\hline$Y_{11}$ & - & 6 & 51 & 22 & - & 3.20 \\
\hline$\overline{Y_{1.2}}$ & - & 7 & 44 & 28 & - & 3.27 \\
\hline$Y_{1.3}$ & 3 & 3 & 47 & 25 & 1 & 3.23 \\
\hline \multicolumn{6}{|c|}{ Total rata-rata } & 3.24 \\
\hline \multicolumn{7}{|c|}{$\begin{array}{l}\text { Keterangan : } 1=\text { Sangat tidak setuju; } 2= \\
\text { Tidak setuju; } 3=\text { Ragu-ragu; } 4=\text { Setuju; } 5= \\
\text { Sangat setuju }\end{array}$} \\
\hline
\end{tabular}

Hasil analisis tentang kepuasan

karyawan dalam kajian ini diukur melalui 3 item pernyataan dengan nilai rata-rata sebesar 3.24 yang berarti bahwa responden memilih jawaban netral dengan seluruh item pernyataan pernyataan tentang kepuasan karyawan. Item pernyataan yang relatif lebih baik dalam menjelaskan variabel ini adalah item pernyataan dukungan rekan kerja dan atasan $\left(\mathrm{Y}_{1 \cdot 2}\right)$ dengan nilai rata-rata tertinggi yakni 3.27.

\section{Metode Analisis Data}

\section{Uji Instrumen Penelitian}

Pengujian instrument dalam penelitian ini dimaksudkan untuk menguji kesahihan atau keabsahan dari kuesioner yang digunakan peneliti. Selanjutnya pengujian ini akan dibahas dalam dua bagian yakni uji validitas dan uji reliabilitas seperti yang diuraikan dibawah ini.

\section{Uji Validitas}

Pengujian validitas dalam kajian ini mengunakan korelasi Product Moment Person, dimana valid atau tidaknya instrumen dapat diketahui dengan membandingkan indeks korelasi Product Moment Person dengan signifikan $5 \%$. Artinya bila probabilitas hasil korelasi lebih kecil dari 0.05 maka instrumen dinyatakan tidak valid dan sebaliknya, jika hasil korelasi lebih besar dari 0.05 maka instrumen dinyatakan valid. Berikut ini adalah hasil pengujian validitas yang ditampilkan dibawah ini;

\section{Hasil Pengujian Validitas}

\begin{tabular}{|c|c|c|c|c|}
\hline \multirow{2}{*}{ Variabel } & \multirow{2}{*}{ Item } & \multicolumn{3}{|c|}{$\begin{array}{c}\text { Korelasi Product } \\
\text { Moment }(\mathbf{r})\end{array}$} \\
\cline { 3 - 5 } & & $\mathbf{r}$ & $\mathbf{s i g}$ & $\begin{array}{c}\text { Keteran } \\
\text { gan }\end{array}$ \\
\hline \multirow{4}{*}{$\begin{array}{c}\text { Lingkungan } \\
\text { Kerja Fisik } \\
\left(\mathrm{X}_{1}\right)\end{array}$} & $\mathrm{X}_{1.1}$ & 0.625 & 0.000 & Valid \\
\cline { 2 - 5 } & $\mathrm{X}_{1.2}$ & 0.938 & 0.000 & Valid \\
\cline { 2 - 5 } & $\mathrm{X}_{1.3}$ & 0.841 & 0.000 & Valid \\
\cline { 2 - 5 } & $\mathrm{X}_{1.4}$ & 0.903 & 0.000 & Valid \\
\hline \multirow{2}{*}{$\begin{array}{c}\text { Lingkungan } \\
\text { Kerja } \\
\text { Non Fisik } \\
\left(\mathrm{X}_{2}\right)\end{array}$} & $\mathrm{X}_{2.1}$ & 0.894 & 0.000 & Valid \\
\cline { 2 - 5 } & $\mathrm{X}_{2.2}$ & 0.902 & 0.000 & Valid \\
\cline { 2 - 5 } & $\mathrm{X}_{2.3}$ & 0.865 & 0.000 & Valid \\
\cline { 2 - 5 } \begin{tabular}{|} 
Kepuasan \\
Karyawan \\
$(Y)$
\end{tabular} & $\mathrm{X}_{2.4}$ & 0.880 & 0.000 & Valid \\
\cline { 2 - 5 } & $\mathrm{Y}_{1.2}$ & 0.910 & 0.000 & Valid \\
\cline { 2 - 5 } & $\mathrm{Y}_{1.3}$ & 0.890 & 0.000 & Valid \\
\hline
\end{tabular}

Hasil dari pengujian validitas diatas secara ringkas dapat dilihat berikut ini.

Ringkasan Hasil Pengujian Validitas 


\begin{tabular}{|c|c|c|c|c|}
\hline Variabel & $\begin{array}{c}\text { Jumlah } \\
\text { Item }\end{array}$ & $\begin{array}{c}\mathbf{r} \\
\text { (terkecil- } \\
\text { terbesar) }\end{array}$ & Sig & Ket \\
\hline $\begin{array}{c}\text { Lingkungan } \\
\text { Kerja Fisik }\end{array}$ & 4 & $\begin{array}{c}0.625- \\
0.938\end{array}$ & 0.000 & Valid \\
\hline $\begin{array}{c}\text { Lingkungan } \\
\text { Kerja Non } \\
\text { fisik }\end{array}$ & 4 & $\begin{array}{c}0.865- \\
0.894\end{array}$ & 0.000 & Valid \\
\hline $\begin{array}{c}\text { Kepuasan } \\
\text { Karyawan }\end{array}$ & 3 & $\begin{array}{c}0.890- \\
0.910\end{array}$ & 0.000 & Valid \\
\hline
\end{tabular}

Informasi pada tabel diatas menunjukan bahwa secara keseluruhan variabel penelitian ini dapat dikatakan valid karena tingkat signifikannya 0.000 adalah lebih kecil dari 0.05 .

\section{Uji Reliabilitas}

Pengujian reliabilitas kajian ini menggunakan alpha cronbachs dimana suatu instrumen dapat dikatakan reliabel jika memiliki nilai koefisien keandalan lebih besar atau sama dengan 0.6 artinya apabila $a=0.6$ maka instrumen dapat dikatakan reliabel. Hasil pengujian reliabilitas kajian ini terlihat berikut ini.

Hasil Pengujian Reliabilitas

\begin{tabular}{|l|c|c|}
\hline \multicolumn{1}{|c|}{ Variabel } & $\begin{array}{c}\text { Koefisien } \\
\text { Alpha }\end{array}$ & Keterangan \\
\hline $\begin{array}{l}\text { Lingkungan } \\
\text { Kerja Fisik }\end{array}$ & 0.848 & Reliabel \\
\hline $\begin{array}{l}\text { Lingkungan } \\
\text { Kerja Non Fisik }\end{array}$ & 0.897 & Reliabel \\
\hline $\begin{array}{l}\text { Kepuasan } \\
\text { Karyawan }\end{array}$ & 0.872 & Reliabel \\
\hline
\end{tabular}

Seluruh variabel terteliti dalam kajian ini ternyata memiliki koefisien korelasi diatas 0.60 sehingga seluruh data penelitian ini dapat dikatakan realibel yang artinya data ini layak untuk dilanjutkan pada pengolahan data tahapan selanjutnya.

\section{Uji Asumsi Klasik}

\section{Uji Normalitas}

Pengujian normal tidaknya dostribusi data penelitian ini dilakukan dengan melihat peneyebaran data pada normal probability plot. Asumsinya, data dikatakan berdistribusi normal apabila data tersebut menyebar mengikuti garis diagonal, penyebarannya secara acak dan tidak membentuk pola tertentu. Tampilan normal probability plot data penelitian ini terlihat dibawah ini;

\section{Hasil Pengujian Normalitas}

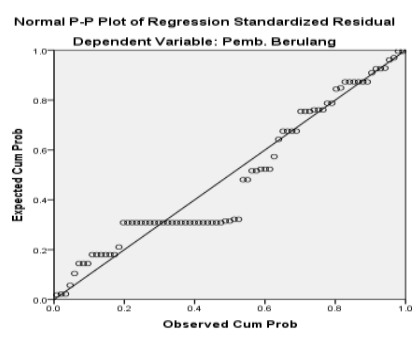

Berdasarkan

normal probability plot diatas, maka data penelitian ini dapat dikatakan telah memenuhi kaidah normalitas karena terlihat bahwa data menyebar mengikuti garis diagonal, 
penyebarannya secara acak dan tidak membentuk pola tertentu.

\section{Uji Heterokedastisitas}

Pengujian

heteroskedastisitas dalam penelitian ini dilakukan dengan melihat gambar charts scatterplot. Model regresi yang bebas heteroskedastisitas jika penyebaran data tidak membentuk pola yang jelas, serta titik-titik menyebar diatas dan dibawah angka 0 pada sumbu $Y$, maka tidak terjadi heterokedastistas. Berikut ini adalah hasil pengujian heteroskedastisitas yang terlihat pada gambar charts scatterplot dibawah ini.

\section{Hasil Pengujian Heterokedastisitas}

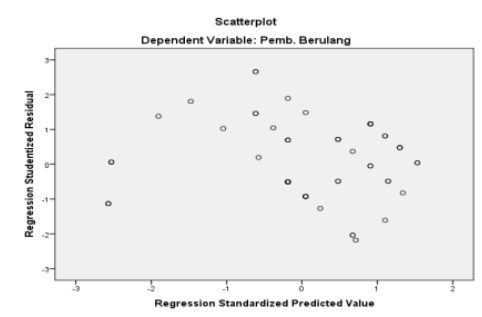

Gambar diatas menunjukan bahwa data penelitian bebas heterokedastisitas karena titik-titik data menyebar diatas dan dibawah angka 0 pada sumbu $\mathrm{Y}$.

\section{Uji Multikoliniearitas}

Pengujian multikolinearitas kajian ini menggunakan melihat nilai Variance Inflation Faktor (VIF) atau faktor pertambahan ragam. Apabila nilai VIF lebih besar dari 10 maka terjadi multikolinieritas, sebaliknya apabila VIF lebih kecil dari 10 maka tidak terjadi multikolinieritas. Berikut ini adalah hasil Pengujian multikolinearitas seperti yang terlihat dibawah ini.

\section{Hasil Pengujian Multikolinieritas}

\begin{tabular}{|l|c|c|}
\hline \multirow{2}{*}{ Model } & \multicolumn{2}{|c|}{ Collinearity Statistics } \\
\cline { 2 - 3 } & Tolerance & VIF \\
\hline Lingkungan Kerja Fisik & 0.087 & 9.499 \\
\hline $\begin{array}{l}\text { Lingkungan Kerja Non } \\
\text { Fisik }\end{array}$ & 0.087 & 9.499 \\
\hline
\end{tabular}

Data diatas menunjukan bahwa nilai tolerance tidak lebih dari 1 dan nilai Variance Inflation Faktor (VIF) berada dibawah 10 yang berarti tidak terjadi multikolinearitas antar variabel independen dalam penelitian ini.

\section{Uji Regresi Linier Berganda}

Dalam penelitian ini analisis regresi linier berganda digunakan oleh peneliti untuk mengetahui pengaruh lingkungan kerja fisik dan lingkungan kerja non fisik terhadap kepuasan karyawan Matahari Departemen Store pada ACC di Kota Ambon. Berikut ini hasil analisis regresi berganda yang terlihat pada Tabel 4.9 dibawah ini.

Hasil Pengujian Regresi Linier Berganda

Variabel Coef. hitung 


\begin{tabular}{|c|l|l|l|l|}
\hline Constant & 1.786 & \multicolumn{3}{|l|}{} \\
\hline $\begin{array}{c}\text { Lingkungan } \\
\text { Kerja Fisik }\end{array}$ & 0.348 & 2.598 & 0.011 & Sig. \\
\hline $\begin{array}{c}\text { Lingkungan } \\
\text { Kerja Non } \\
\text { Fisik }\end{array}$ & 0.288 & 2.039 & 0.045 & Sig. \\
\hline $\begin{array}{c}\text { Adjusted R } \\
\text { Square }\end{array}$ & 0.761 & \multicolumn{4}{|l|}{} \\
\hline t tabel & 1.664 & \multicolumn{4}{|l|}{} \\
\hline
\end{tabular}

Dari data diatas menunjukan

bahwa persamaan regresi dalam penelitian ini adalah sebagai berikut;

$Y=a+\beta_{1} X_{1}+\beta_{2} X_{2}+\varepsilon$

$Y=1.786+0.348+0.288+\varepsilon$

Data diatas menunjukan

nilai constant atau intercept sebesar

1.786 mengartikan bahwa jika tidak ada kenaikan nilai dari lingkungan kerja fisik dan lingkungan kerja non fisik maka besarnya nilai kepuasan karyawan Matahari Departemen Store pada ACC di Kota Ambon adalah sebesar 1.786. Koefisien regresi lingkungan kerja fisik sebesar 0.348 menunjukkan bahwa setiap nilai lingkungan kerja fisik meningkat atau semakin baik maka nilai kepuasan karyawan Matahari Departemen Store pada ACC di Kota Ambon akan meningkat sebesar nilai koefisien regresi lingkungan kerja fisik tersebut atau dengan kata lain setiap peningkatan kepuasan karyawan Matahari Departemen Store pada ACC di Kota Ambon dibutuhkan nilai lingkungan kerja fisik sebesar 0.348 dengan asumsi besarnya nilai lingkungan kerja non fisik adalah tetap.

Koefisien regresi lingkungan kerja non fisik sebesar 0.288 menunjukkan bahwa setiap nilai lingkungan kerja non fisik meningkat atau semakin baik maka nilai kepuasan karyawan Matahari Departemen Store pada ACC di Kota Ambon akan meningkat sebesar nilai koefisien regresi lingkungan kerja non fisik tersebut atau dengan kata lain setiap peningkatan kepuasan karyawan Matahari Departemen Store pada ACC di Kota Ambon dibutuhkan lingkungan kerja non fisik sebesar 0.288 dengan asumsi besarnya nilai lingkungan kerja fisik adalah tetap.

Data diatas juga menunjukan bahwa model konseptual penelitian yang dibangun adalah layak karena terbukti bahwa variabel kepuasan karyawan dapat dijelaskan dengan baik oleh variabel lingkungan kerja fisik dan lingkungan kerja non fisik dengan nilai determinasi atau tingkat kelayakan sebesar 0.761 atau sebesar $76.1 \%$ sementara sisanya sebesar $23.9 \%$ lainnya dijelaskan oleh variabel lain yang tidak diuji dalam model konseptual penelitian ini. 


\section{Pembahasan Hasil Penelitian}

Hasil analisis regresi linier berganda diatas menunjukan bahwa lingkungan kerja fisik dan lingkungan kerja non fisik terbukti memiliki pengaruh yang positif dan signifikan terhadap tingkat kepuasan kerja karyawan Matahari Departemen Store pada ACC di Kota Ambon. Temuan ini membuktikan bahwa peningkatan lingkungan kerja fisik dan lingkungan kerja non fisik juga akan diikuti dengan peningkatan kepuasan kerja karyawan Matahari Departemen Store pada ACC di Kota Ambon.

Variabel lingkungan kerja fisik dalam kajian ini terwakili oleh 4 pernyataan yang berdasarkan analisis deskriptif terlihat bahwa item pernyataan yang dominan memberikan dampak terhadap tingkat kepuasan kerja adalah item pernyataan tentang ketersediaan fasilitas pekerjaan yang disediakan perusahaan item $\left(\mathrm{X}_{1.1}\right)$. Dimana, karyawan merasa puas dengan ketersediaan fasilitas pekerjaan yang telah disediakan oleh pihak Matahari Departement Store ACC. Hal ini juga didukung oleh hasil analisis inferensal melalui analisis regresi linier berganda yang membuktikan bahwa besarnya nilai koefisien lingkungan kerja fisik menunjukan nilai yang positif
(0.348) dan besarnya nilai $t$ hitung lingkungan kerja fisik yakni 2.598 adalah lebih besar jika dibandingkan dengan $t$ tabel yakni $1.664(2.598>1.664)$ dengan tingkat signifikansinya sebesar 0.011 adalah lebih kecil dari $0.05(0.011<0.05)$. Hasil analisis ini membuktikan bahwa lingkungan kerja fisik terbukti berpengaruh positif dan signifikan terhadap kepuasan kerja karyawan Matahari Departemen Store pada ACC di Kota Ambon.

Selanjutnya, variabel lingkungan kerja non fisik dalam kajian ini dibentuk oleh 4 item pernyataan. Hasil analisis deskriptif melalui distribusi frekuensi jawaban responden memberi gambaran bahwa item pernyataan yang dominan memberikan dampak terhadap tingkat kepuasan kerja adalah item pernyataan tentang hubungan atasan dan bawahan $\left(\mathrm{X}_{2 \cdot 3}\right)$. Dimana, karyawan Matahari Departement Store ACC mengakui bahwa baiknya hubungan atasan dan bawahan dilingkungan kerja dipersepsikan mampu meningkatkan tingkat kepuasan kerja. Hasil analisis dekriptif ini juga didukung oleh hasil analisis regresi linier berganda yang menunjukan bahwa besarnya lingkungan kerja non fisik memiliki pengaruh positif yakni 0.288 dan besarnya nilai $t$ tabel yakni sebesar 2.039 adalah lebih besar dari nilai $\mathrm{t}$ hitung yakni 1.664 (2.0039> 1.664) dengan 
besarnya nilai signifikan sebesar 0.045 yang adalah lebih kecil dari 0.05 (0.045 $<0.05)$. Hasil analisis ini membuktikan bahwa lingkungan krja non fisik memiliki pengaruh positif dan signifikan terhadap kepuasan kerja karyawan Matahari Departemen Store pada ACC di Kota Ambon. Temuan ini mendukung hasil kajian empiris oleh; (Pangarso, 2015); (Marezza Putri Anggreani, 2016); (Dwi Silvia Eka S., 2016); (Untung Dasio dan Nugraheni Rini, 2017) dan (Zulfahmi Septian Dwi Pangestu, 2017) yang keseluruhannya mengakui bahwa lingkungan kerja fisik dan lingkungan kerja non fisik berpengaruh terhadap kepuasan kerja karyawan.

\section{Daftar Pustaka}

(http://www.medanbisnisdaily.com.

(2014, February 19). Rendahnya Tingkat Kepuasan Para Pekerja Indonesia. Retrieved from http://www.medanbisnisdaily.com/ news/read/2014/02/19/79886/ren dahnya_tingkat_kepuasan_para_p ekerja_indonesia/

Agusty Ferdinand. (2006). Metode

Penelitian Manajemen; Pedoman Penelitian Untuk Penulisan Skripsi, Tesis Dan Disertasi IImu Manajemen (Edisi Kedua). Semarang: Badan Penerbit

\section{Simpulan}

Berdasarkan hasil analisa diatas menunjukan bahwa lingkungan kerja fisik dan lingkungan kerja non fisik terbukti memiliki pengaruh yang positif dan signifikan terhadap tingkat kepuasan kerja karyawan Matahari Departemen Store pada ACC di Kota Ambon. Temuan ini membuktikan bahwa peningkatan lingkungan kerja fisik dan lingkungan kerja non fisik juga akan diikuti dengan peningkatan kepuasan kerja karyawan Matahari Departemen Store pada ACC di Kota Ambon.

Universitas Diponegoro.

Dwi Silvia Eka S., B. S. S. dan H. N. U. (2016). Pengaruh Lingkungan Kerja Fisik dan Non Fisik Terhadap Kepuasan Kerja dan Kinerja Karyawan (Studi pada karyawan PT Telkom Indonesia Witel Jatim Selatan Malang). Jurnal Administrasi Bisnis (JAB), 40(1), 76-85.

Fred Luthans. (2002). Organizational Behavior: 7th Edition. McGraw-Hill Inc.

gaya.tempo.co. (n.d.). Lingkungan Kerja Buruk Akibatnya Depresi dan 
Sering Bolos. Retrieved from https://gaya.tempo.co/read/10234

72/lingkungan-kerja-buruk-

akibatnya-depresi-dan-sering-

bolos/full\&view=ok

Jasman Saripuddin. (2015). Pengaruh

Lingkungan Kerja dan Budaya

Organisasi Terhadap Kepuasan

Kerja Karyawan pada PT. Sarana

Agro Nusantara Medan. Medan.

lifestyle.kompas.com. (2018, February

1). Kurang Apresiasi 30\% Pekerja

Indonesia Ingin Pindah. Retrieved from

https://lifestyle.kompas.com/read/

2018/01/02/214530820/kurang-

apresiasi-30-persen-pekerja-

indonesia-ingin-pindah-kerja

M. Sandi Marta dan Budi. (2019).

Lingkungan Kerja, Mungkinkah

Tidak Berpengaruh Terhadap

Kepuasan Kerja? Manajerial, 18

(1), 27-39.

Mangkunegara, A.A., dan Prabu, A.

(2011). Manajemen Sumber Daya

Manusia Perusahaan. Bandung:

PT. Remaja Rosda Karya.

Marezza Putri Anggreani, I. dan N. W.

(2016). Pengaruh Lingkungan

Kerja Non Fisik dengan Kepuasan

Kerja sebagai Variabel Intervening

terhadap Turnover Intention

Karyawan PT. Andika Lintas

Samudera Banjarmasin Jurnal
Bisnis dan Pembangunan , Edisi Juli-Desember 2016, Jurnal Bisnis

Dan Pembangunan, 5(2), 51-56.

Moekijat. (1995). Manajemen

Kepegawaian. Bandung: Alumni.

Pangarso, A. dan V. R. (2015).

Pengaruh Lingkungan Kerja Non

Fisik Terhadap Kepuasan Kerja

Dosen Tetap Studi pada Fakultas

Komunikasi dan Bisnis Universitas

Telkom Bandung. Kinerja, 19(1), 172-191.

Robbins, S. P. (2002). Prinsip-Prinsip

Perilaku Organisasi. Jakarta:

Erlangga.

Sedarmayanti. (2001). Sumber Daya Manusiadan Produktivitas Kerja. Jakarta: Mandar Maju.

Sunyoto. (2012). Perilaku dalam Organisasi. Yogyakarta: CV. Andi Offset.

Tamaela Eduard \& Surijadi Herman.

(2014). Pengaruh Kepuasan Kerja, Motivasi Kerja dan Komitmen Organisasional Terhadap Kinerja Pegawai SKPD di Kabupaten Jayapura. Benchmark (Jurnal Ekonomi, Bisnis Dan Akuntansi), 2(3), 111-124. Retrieved from www.Ipebmaluku.org

Tukijan. (2016). Pengaruh Lingkungan Kerja Non Fisik dan Lingkungan Kerja Fisik Terhadap Kepuasan Kerja Pegawai Pada STISIP Amal 
Ilmiah Yapis Wamena. Ji@P, 3 (2), 136-145.

Untung Dasio dan Nugraheni Rini. (2017). Pengaruh Lingkungan Kerja Fisik dan Lingkungan Kerja Non Fisik Terhadap Kinerja Karyawan dengan Kepuasan Kerja Sebagai Variabel Intervening (Studi pada Karyawan Bagian Weaving PT. Primatexco Indonesia). Diponegoro Journal of
Management, 6(4), 1-12. Wursanto. (2009). Dasar-Dasar IImu Organisasi. Yogyakarta: Andi. Zulfahmi Septian Dwi Pangestu, M. D. M. dan I. R. (2017). Pengaruh Lingkungan Kerja Terhadap Kepuasan Kerja (Studi pada Karyawan Perum Perhutani Ngawi). Jurnal Administrasi Bisnis (JAB), 43(1), 157-162. 